\title{
A corpus-based approach to lessons development for EFL reading course
}

\author{
Anchalee Veerachaisantikul ${ }^{1 *}$, Wara Chansin ${ }^{2}$ \\ ${ }^{1}$ Rajamangala University of Technology Isan, Nakhon Ratchasima, Thailand \\ 2 Naresuan University, Tha Pho, Phitsanulok, Thailand
}

\author{
Keywords \\ Corpus based approach \\ Lessons development \\ EFL \\ Reading
}

Received: 15 Agust 2018 Accepted: 11 September 2018 Published: 31 October 2018

\begin{abstract}
The purposes of the current study were to develop the corpus-based lessons in reading English newspaper course and to determine the effectiveness of the corpus-based vocabulary exercises. The samplings of the study were forty-three-third year students majoring English, the Faculty of Sciences and Liberal Arts, Rajamangala University of Technology Isan. To instruct the selected 50 vocabulary words, the corpus-based vocabulary exercises were constructed on a theoretical framework developing from the Constructivism Theory, Second Language Acquisition Theory, and Vocabulary Learning and Teaching Theories that were used for a period of 10 weeks. The research instruments of the current study were the pre-test, the post-test, and the questionnaire. The quantitative data were analyzed through the paired sample t-test and the qualitative data were analyzed by using the software package. The findings reveal that using corpus-based lessons were effective and could help EFL students to improve their vocabulary knowledge, perceive the words, comprehend the meaning of the words, and also employ the words properly in the news contexts. On the basis of these findings, future recommendations for scholars are discussed.
\end{abstract}

(c) 2018 The Author(s). Published by TAF Publishing.

\section{INTRODUCTION}

As the expansion of globalization, English has become more and more important alongside the world today. In addition, it is known as the most powerful lanaguage for the international relations with over a quarter of the world. It is also understood or spoken by over 1 billion people and approximately 400 million native speakers speaking the English language. As developing country, Thailand has participated in international business and commerce thus the prerequisite of using English for communication with other countries is very important. It has been provided as an international lanaguage in order to use not only as a way of transferring thoughts and ideas but also use as a channel for forging cultural ties, and diplomatic relations, economy, and education (Chaimongkol, 2000). For these reasons, it is considered as the fundamental prerequisite for people whose their first language is not English and incorporated into the educational system in various countries all over the world. Thailand also gives importance to English education, and the government has provided English instruction from primary school to university. The objective of language learning for Thais is to be able to use it for communication in their everyday lives and their study at higher level.

In the world today, reading is one of the most accepted and substantial ways of learning other languages that also helps students to develop their knowledge. Due to the increasing use of English in international contexts, students' perception of reading is an essential feature and the competence of reading in English has become needed for them especially in EFL contexts where English is used as a foreign language, hence reading has been highlighted as the important skill (Abdul Amir, 2015; Robb \& Susser, 1989). In the same way, it is unavoidable to follow the changing world so it can be noted that it is necessary for students to spend a lot of time in reading various sorts of written texts that serve pratical information (Clark, 1988; Hilao, 2016). One primary kind of reading material is newspaper that is regarded as one of the most accepted sources of knowledge, forward-

*corresponding author: Anchalee Veerachaisantikul

†email: anchaee.ve@rmuti.ac.th 
ing news, entertainment and ideas for the readers. Moreover, newspaper conveys news and information to a considerable number of readers in very short time because of its functions which speaks to their readers in their readers' language (Junnak \& Veerachaisantikul, 2016; Photi, 1997). Thus, people could apply them as a basic source for forwarding various sorts of skills and knowledge. Kyongho and Nation (1989) suggested that newspaper is much used in reading courses for promoting reading skills and expanding lexical knowledge. There are three reasons for using newspaper in classroom. The first reason is that newspaper is easy and cheap to access both in hard copy and online version. It is also an authentic lessons that is generally read by the native speakers and it also serves large alternatives for interesting topics that learners or teachers could select reading texts. In addition, it is not only a good way of brushing up old vocabulary but also a great way of learning new vocabulary from context as well.

Although reading is emphasized in EFL courses for Thai learners, they still have a trouble with vocabulary which is essential to help them understand their texts. Since, many researche in Thailand found that the difficulty in lanaguage learning of Thai students is the lack of vocabulary knowledge (Boonkongsaen \& Intaraprasert, 2014; Chansin, 2007; Duadsuntia, 2008; Taher, Shrestha, Rahman, \& Khalid, 2016).

As suggested by Read (2000) that vocabulary is a word or a group of word combination to make a language that provides a grammatical and lexical function in both spoken and written texts. Additionally, it is fundamental to lanaguage and extremely important to lanaguage learners as knowing vocabulary is a key to comprehension and a large vocabulary can assist learners in learning a language since the more vocabulary students know, the better they understand what they read (Meara, 1996; I. S. Nation, 2001). The outstanding role of vocabulary in language learning has been continuously perceived and there is doubtless that vocabulary acquisition is the most significant needs of any language learners. Consequently, it can be said that vocabulary is very meaningful to help EFL learners to comprehend the language (S. D. Krashen \& Terrell, 1983; S. Krashen, 1989; Leki \& Carson, 1994; Unnanantn, 2017). One of the most effective way to be able to read is knowing the high frequency words as they could help students better understand without hesitation what is being read.

High frequency words are a core of learner's thought in learning vocabulary as recommended by P. Nation and Newton (1997). Students could master these words by perception and accompany them to their vocabulary. Similarly, the competence of understanding words by achieving from encountering them in particular contexts is still fruitful as it could be valuable for learners to accomplish their understanding as well as they could discover new words when they learn with new lessons. Thus, deciding which words should be taught and learners have been controversy in one of the recent trends is to accept that is called corpus linguistics.

Corpus linguistics is used in the language classroom since the 1980s through concordance lines, which are all the instances of a word or node in a corpus. Further, it is compiled for different objective such as English teaching lessons in grammars, books, or dictionaries which display how a language is really used (Boonyarattanasoontorn, 2017; Scott, 2012). As suggested by many researchers that this approach is applied as the fundamental part in vocabulary development and lessons developed by using corpora are accepted to be more authentic and enabled researchers to determine with a high degree of particularity that appearing words and phrases a language learner would take advantage most from studying and (Biber, Conrad, \& Reppen, 1994; McCarthy \& Carter, 1997; Simpson \& Mendis, 2003). In this way, selecting the vocabularies that are most frequent and useful to guarantee the contexts in which words are used as authentic ones, based on the contexts that appear in corpora and most related to their EFL lives, is undeniably necessary. Consequently, the main reason for undertaking the current study is to simplify the reading English newspaper comprehension by building up familiarity with English newspaper key words and develop EFL corpus-based lessons for reading English newspaper.

\section{Objectives of the Study}

The purposes of the current study are as follows:

1. To develop the reading English newspaper corpus-based materials for EFL students.

2. To determine the effectiveness of the reading English newspaper corpus-based materials.

\section{METHODOLOGY}

\section{The Samplings}

Forty-three students majoring English who enrolled in the Reading English Newspaper course in their third year were selected by the purposive sampling method.

\section{The Source of Data for the Corpus}

The source of data for the English Newspaper Corpus (ENC) analysis is the online news articles from the general, business, and sports section of the Nation Newspaper during the period of one month from April 1st to April 30 th, 2018 
(Veerachaisanitkul, 2017). The total numbers of news articles were 422 files and the total number of tokens or running word were 198,742 words. As mentioned earlier, the current study aimed to investigate high frequency words and key words in order to use as data of developing the course lessons thus English news articles in an online version during the period of one month were chosen as a significant input for this study. The information of the current corpus is shown in Table 1.

TABLE 1. General statistic of each file

\begin{tabular}{lllll}
\hline \hline & General & Sports & Business & Total \\
\hline No. of articles & 150 & 151 & 121 & 422 \\
No. of tokens & 86,992 & 69,004 & 42,746 & 198,742 \\
Word types & 8,529 & 6,837 & 5,479 & 20,845 \\
\hline \hline
\end{tabular}

According to Table 1, the token running words of each file were 86,992 for general, 69,004 for sports, and 42,746 for business. The general file had the highest number of to- ken words while the business file had the smallest number of tokens. As for word types, the general file also had the highest number of the different word types $(8,529)$ whereas the business file had the smallest number of different word types.

\section{Procedures of Corpus Construction}

The research procedures of this study consisted of eight steps in order to profile the ENC. The method of data analysis can be illustrated in Figure 1 which are relevant to how data were investigated and how to create a selection of texts in order to achieve the top 50 most frequently occurring word list.

\section{Step 1: The news articles in HTML (online)}

To achieve the data, the news articles in the general, business, and sports section of the online version were applied as significant data for this study. The news articles were collected for a period of one month from April 1st to April 30 th, 2018.

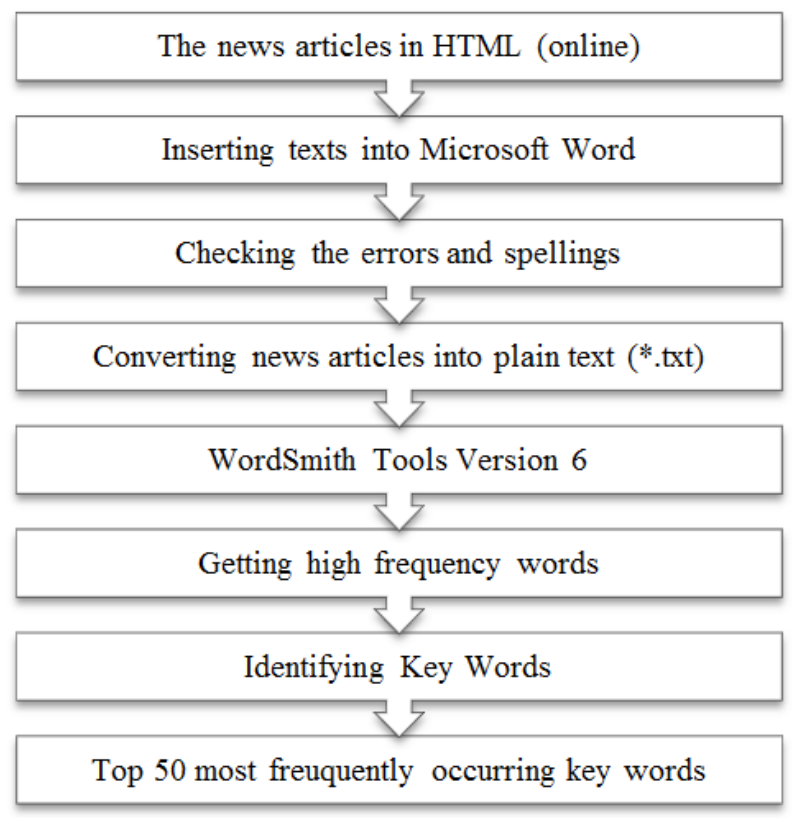

FIGURE 1. Procedures of corpus construction

\section{Step 2: Inserting text into microsoft word}

Thereafter gaining the data in HTML format, the online texts from the general, business, and sports news articles were inserted into "plain text" (*.txt) and the total of news articles were 422 files.

\section{Step 3: Checking the errors and spelling}

The checking of the errors and spellings of the words analysis were checked before adopting texts into the analyzing program by this step.
Step 4: Converting news articles into plain text (*.txt) After checking of the errors and spellings in word documents $(*$ doc) then we saved all news articles as plain texts in order to make the analyzing program better.

\section{Step 5: WordSmith tools version 6}

All news articles were inserted into the "WordSmith Tools Version 6" (Scott, 2012) for analyzing the most frequent words in the ENC. 


\section{Step 6: Getting high frequency words}

After inserting all news articles into the "WordSmith Tools Version 6", the program was given the high frequency words in the text files.

\section{Step 7: Classifying the key words in newspaper}

After getting the most frequently words of the ENC, the frequency words list was eyed by applying the Oxford Advanced Learner's Dictionary manually to classify the key words. Later, the top 50 most frequently occurring key words were achieved. Moreover, these words occurring in the ENC at least 50 times.

\section{Procedures of Making Lessons}

The reading English newspaper lessons consisted of six activities. These activities composed of 50 words to be studied and each lesson comprised 10 words, which were presented in six vocabulary activities. The six vocabulary activities included.

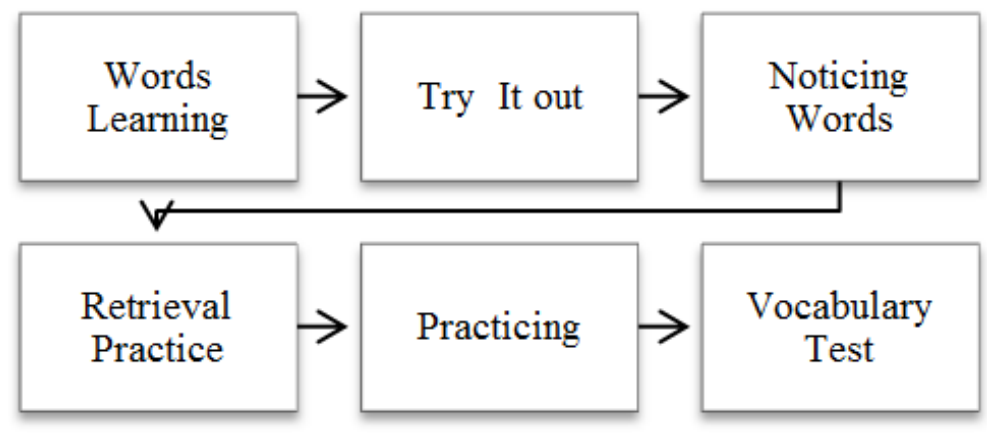

FIGURE 2. Procedures of making lessons

\section{Words learning}

This activity was designed to help the students to realize the 10 target words and introduced the target words to samplings that to be learned in each activity. The 10 words is a proper number of words per lesson as mentioned by Wallace (1984). Thus, the target words in each lessons were ordered alphabetically in order to improve the awareness of the meaning of words.

\section{Try it out}

It is an activity that aimed to check which of the target words they know and do not know. After learning words, the students need to check out their vocabulary knowledge first for getting the picture of their learning improvement (Read, 2000).

\section{Noticing words}

This activity was created to remark the target words that students should pay attention to the unknown words. It was planned to emphasize learners to the target words (I. S. Nation, 2001).

\section{Retrieval practice}

It is an activity which students can guess the meaning of target words from contexts. In this practice, students might perceive words and comprehend their meanings toward texts throughout the exercise, or the teacher's explanation or dictionary using. This way can help students to memory the words better when they recall those words during the task.

\section{Practicing}

This activity focused on practicing students with vocabulary by matching, gap filling, and word association. It is required students to remember the target words and at least of their meanings or requiring just partial knowledge of students.

\section{Vocabulary test}

It is designed to rate the development of students in their vocabulary learning after accomplishing each lesson. As I. S. Nation (2001) stated that students should know their learning development in order to get an evaluation after learning.

\section{Research Instruments \\ The pre-test and post-test}

The pre-test and post-test were used as tone of important research instruments in the current study. The pre-test was designed to set up the guideline to the samplings and the post-test was purposed to examine whether the students have accomplished their improvement or not after they have learnt the target words through the lessons. The pre-test and post-test were divided into two parts that are multiple choices and translation test.

The first part contained 30 multiple-choice questions with four alternatives. When they make multiple answers, they 
will receive one point for every correct answer and receive zero point for every wrong answer. The second part is translation part comprised of 30 items to evaluate the students' understanding of perceiving the target words and comprehend their meanings. The translation test was designed by incidentally choosing 30 out of 50 target words that students have learnt in the lessons. In this part, students have to translate the meanings of target words from English to Thai with the answer keys which was based on the dictionaries.

\section{The checklist questionnaires}

The current study was used two questionnaires in order to get the valid results. The first questionnaire aimed to explore the point of views of students in order to find out the effectiveness of the reading English newspaper corpusbased materials. This questionnaire inquired about the students' opinions on the lessons.

For the second questionnaire, it was designed to know the opinions of the students on their vocabulary improvement after learning the target words through the reading English newspaper corpus-based materials. Both of questionnaires consisted of two main parts: general information and opin- ion on their vocabulary learning improvement after learning the through reading English newspaper corpus-based materials. In order to evaluate the results, the Likert's scale was used in the current study. The Likert's scale has five classifications and comprises of a description and the explanatory description and a sequence answer were fivepoint rating scales used for asking the students' opinion are as follows:

5 = Strongly Agree

$4=$ Agree

$3=$ Neutral

$2=$ Disagree

1 = Strongly Disagree

\section{RESULTS}

The purposes of the current study were to develop the reading English newspaper corpus-based materials and to determine the effectiveness of the corpus-based lessons whether it improved the EFL students' vocabulary knowledge. The pre-test and post-test were used as the research instruments to obtain the findings of research purposes. The quantitative data were analyzed through the paired sample $t$-test.

TABLE 2. Pre test and post test scores

\begin{tabular}{|c|c|c|c|c|c|}
\hline No. of Students & Pre- Test & Post- Test & No. of Students & Pre- Test & Post- Test \\
\hline 1st student & 25 & 40 & 23rd student & 36 & 56 \\
\hline 2nd student & 22 & 45 & 24 th student & 31 & 42 \\
\hline 3rd student & 30 & 42 & 25 th student & 33 & 53 \\
\hline 4th student & 18 & 35 & 26 th student & 22 & 38 \\
\hline 5th student & 20 & 40 & 27 th student & 28 & 45 \\
\hline 6th student & 32 & 50 & 28 th student & 25 & 42 \\
\hline 7th student & 31 & 53 & 29 th student & 27 & 50 \\
\hline 8th student & 27 & 43 & 30 th student & 35 & 55 \\
\hline 9th student & 22 & 48 & 31st student & 37 & 56 \\
\hline 10th student & 18 & 36 & 32nd student & 33 & 56 \\
\hline 11 th student & 26 & 45 & 33rd student & 41 & 55 \\
\hline 12 th student & 30 & 45 & 34 th student & 25 & 39 \\
\hline 13 th student & 28 & 39 & 35 th student & 33 & 48 \\
\hline 14 th student & 29 & 45 & 36 th student & 26 & 49 \\
\hline 15 th student & 17 & 32 & 37 th student & 17 & 33 \\
\hline 16 th student & 24 & 42 & 38 th student & 29 & 49 \\
\hline 17 th student & 35 & 53 & 39 th student & 45 & 56 \\
\hline 18 th student & 28 & 49 & 40 th student & 27 & 50 \\
\hline 19 th student & 38 & 55 & 41st student & 29 & 52 \\
\hline 20 th student & 40 & 56 & 42nd student & 36 & 54 \\
\hline 21st student & 26 & 48 & 43rd student & 30 & 53 \\
\hline \multirow[t]{3}{*}{ 22nd student } & 23 & 40 & & & \\
\hline & & & $\mu$ & 28.69 & 46.79 \\
\hline & & & $\sigma$ & 6.56 & 6.95 \\
\hline
\end{tabular}


Table 2 showed the mean score $(\mu)$ of the pre-test was 28.69 and the standard deviation $(\sigma)$ was 6.56 . It can be seen that in the post-test the mean score of all students was higher after learning through the lessons. The mean score $(\mu)$ of the post-test was 46.79 and the standard deviation $(\sigma)$ was 6.95. Furthermore, the results of the pre-test revealed that there were 20 students who had the score below mean level which accounted for 46.51 percent. There were also 19 students who received the above level of mean score value that accounted for 41.3 percent. Besides, the results of post-test exhibited that there were 20 students who had the score below mean level. However, it can be seen that students have made good progress in their vocabulary learning through the lessons when looking at the pre-test score.
TABLE 3. The maximum and minimum score of the pre-test and post-test

\begin{tabular}{lll}
\hline \hline Test & Minimum & Maximum \\
\hline Pre-test & 17 & 45 \\
Post-test & 32 & 56 \\
\hline \hline
\end{tabular}

Table 3 displayed the minimum scores of the pre-test was 17 while the minimum score of the post-test was 32 . For the maximum score of the pre-test 45 whereas the maximum score of the post-test was 56. This can be supposed that after learning through the lessons, students have made progress in vocabulary learning.

TABLE 4. Students' opinion on the reading English newspaper corpus-based lessofvns

\begin{tabular}{|c|c|c|c|}
\hline Items & $\overline{\bar{X}}$ & S.D. & Level \\
\hline 1. The lessons is easy to employ and understand. & 4.48 & 0.55 & High \\
\hline 2. The lessons has a variety of learning activities. & 4.22 & 0.45 & High \\
\hline 3. The content is interesting. & 4.44 & 0.65 & High \\
\hline 4. The content fits your needs. & 4.40 & 0.89 & High \\
\hline $\begin{array}{l}\text { 5. The content is suitable for your level of } \\
\text { knowedge. }\end{array}$ & 4.04 & 0.56 & High \\
\hline 6. The presentation of content well-organized. & 4.01 & 0.87 & High \\
\hline 7. The content is explained clearly. & 4.05 & 0.48 & High \\
\hline 8. The direction of the lessons are clear. & 4.38 & 0.58 & High \\
\hline 9. The time to do each exercise is suitable. & 4.14 & 0.66 & High \\
\hline $\begin{array}{l}\text { 10. The language used in each exercise is clear, the } \\
\text { students can comprehend and do the activity cor- } \\
\text { rectly. }\end{array}$ & 4.39 & 0.67 & High \\
\hline $\begin{array}{l}\text { 11. The difficulty level of the exercise is suitable for } \\
\text { practicing. }\end{array}$ & 4.41 & 0.89 & High \\
\hline $\begin{array}{l}\text { 12. The number of exercises is suitable for practic- } \\
\text { ing. }\end{array}$ & 4.45 & 0.54 & High \\
\hline $\begin{array}{l}\text { 13. The number of } 10 \text { target words words in each } \\
\text { exercise is sufficient. }\end{array}$ & 4.48 & 0.59 & High \\
\hline $\begin{array}{l}\text { 14. All excercises are enough to make students } \\
\text { comprehend the meaning of the words precisely. }\end{array}$ & 4.29 & 0.41 & High \\
\hline \multirow{2}{*}{$\begin{array}{l}\text { 15. The types of excercises used in the lessons are } \\
\text { various styles and interesting. }\end{array}$} & 4.11 & 0.66 & High \\
\hline & 4.29 & 0.95 & High \\
\hline
\end{tabular}

As shown in Table 4, student's opinion on the reading English newspaper corpus-based lessons was satisfied at high level with the mean score of 4.29. According to the results, it can be seen that the students felt the content of the lessons are interesting, fit their needs, and suitable with their knowledge with the mean score $(\bar{X})=4.44,4.40$, and 4.04 respectively. 
TABLE 5. Students' opinion after using the lessons

\begin{tabular}{|c|c|c|c|}
\hline Items & $\bar{X}$ & S.D. & Level \\
\hline 1. The lessons support me to improve my vocabulary knowledge. & 4.39 & 0.59 & High \\
\hline 2. The lessons develop my skill of guessing word meaning from context clues. & 4.33 & 0.57 & High \\
\hline 3. The lessons encourage me to remember the target words. & 4.29 & 0.48 & High \\
\hline 4. The lessons provide me to comprehend the meaning of the target words. & 4.39 & 0.52 & High \\
\hline 5. The lessons make me ready to use the target words in contexts. & 4.21 & 0.85 & High \\
\hline 6. The lessons provide me to learn the words appearing in our everyday life. & 4.06 & 0.78 & High \\
\hline 7. The lessons help me to be able to employ the target words accurately. & 4.28 & 0.56 & High \\
\hline 8. The exercises contained in the lessons help me to develop my vocabulary knowledge. & 4.24 & 0.63 & High \\
\hline 9. The matching, gap filling, and word association exercises help me to improve vocabulary knowledge. & 4.47 & 0.60 & High \\
\hline 10. The matching, gap filling, and word association exercises help me to understand the meanings of words. & 4.45 & 0.59 & High \\
\hline 11. The matching, gap filling, and word association exercises make me ready to use the target words in contexts. & 4.33 & 0.88 & High \\
\hline 12. The matching, gap filling, and word association exercises support me to develop my vocabulary knowledge for reading. & 4.48 & 0.95 & High \\
\hline 13. The lessons motivate me to realize the needs of learning the target words to improve my vocabulary knowledge. & 4.45 & 0.84 & High \\
\hline 14. The lessons help me to upgrade my vocabulary knowledge by myself. & 4.36 & 0.72 & High \\
\hline \multirow[t]{2}{*}{ 15. After learning through the lessons, I can recognize the target words better. } & 4.28 & 0.54 & High \\
\hline & 4.33 & 0.85 & High \\
\hline
\end{tabular}

Table 5 displayed student's opinion after using the lessons that they felt it is a useful material as their opionion with the mean score of 4.33 at high level. It can be said that students accepted the vocabulary exercises contained in the lessons help them to improve their vocabulary knowledge. Futher, the students revealed that the lessons motivated them to learn and provide a confidence to develop their vocabulary knowledge.

\section{CONCLUSION}

The current study was carried out with the following purposes: 1) to develop the reading English newspaper corpusbased lessons for EFL students and 2) to determine the effectiveness of the reading English newspaper corpus-based lessons. The two purposes were posed and the answers to these purposes are given as follows.

\section{Research Purpose 1: To Develop the Reading English Newspaper Corpus-Based Materials for EFL Students}

To accomplish this purpose, we gathered 422 news articles from online version of the Nation Newspaper which is one of the popular newspaper in Thailand from April 1st to April 30 th, 2018. We collected the online news articles from the general, business, and sports section then saved them into "Microsoft Word". Before the "WordSmith Tools Version 6" was used to classify the most frequent words and key words of ENC, all files were converted into the plain text $(*$ txt) in order to make the analyzing program effectively. The concordance software "WordSmith Tools Version 6 " was applied. This concordance software was used to see how words behave in texts. It was used in order to make the word frequency lists of news articles files by using the Wordlists Tool that offered both alphabetical and frequency order of the words in the texts files. The total corpus was
198,742 tokens or running words and the number of word types was 20,845 . From the analysis of the study, the top 50 most frequently occurring words of the ENC was obtained. Thereafter, the reading English newspaper lessons that consisted of six activities, were constructed. These activities composed of 50 words to be mastered and each lesson comprised 10 words. The six activities were Word Learning, Try It Out, Noticing Words, Retrieval Practice, Practicing, and Vocabulary Test. These lessons of the reading English newspaper corpus-based lessons were used by the 43 students for a period of 10 weeks.

\section{Research Purpose 2: To Determine the Effectiveness of the Reading English Newspaper Corpus-Based Materi- als}

In order to determine the effectiveness of the English reading lessons, the pre-test and post-test were carried out. The pre-test and post-test were divided into two parts that are multiple choices and translation test. The multiple choices part contained 30 multiple-choice questions with four alternatives. When they make multiple answers, they will receive one point for every correct answer and receive zero point for every wrong answer. The second part is teh translation part comprised of 30 items which were designed by incidentally choosing 30 out of 50 target words that students have learnt in the lessons.

The results revealed that the post-test mean score $(\mu)$ was increased which confirmed that the constructed lessons did support the 43 students to develop their vocabulary knowledge. The results also displayed that students can perceive the words, comprehend the meaning, and apply the words properly with the contexts. This can be concluded that the vocabulary exercises that designed for the lessons could help the students to enhance their vocabulary knowledge 
and help them to recognize the meaning of the target words. Additionally, it can be assumed that students could learn new words approximately 5 to 10 words each time and the number of times that words appear around 7 to 10 times could help them to recognize the words well.

Moreover, the students' opinion revealed that they satisfied the reading English newspaper corpus-based lessons at high level and after learning through the lessons they felt that it is a useful material helps them improve their vocabulary knowledge at the high level.

\section{LIMITATIONS AND RECOMMENDATIONS}

As summarized earlier, there are some recommendation for the further research related to this, described as follows:

a) The further study could be more accurate with collecting a much larger corpus. In addition, other resources of news corpora should be covered to see the broad intensity of linguistic features of news articles. In the current study, the online newspapers were used as an important input for the corpus, hence in order to examine the various linguistics in reading, other authentic texts such as textbooks, magazines, articles and journals should be regard as an input for the corpus study.

b) In the current study, the reading English newspaper corpus-based materials were designed for English major students at Rajamangala University of Technology Isan thus the further study could be used on a great scale of learners both English major and other fields of study who need to increase and develop their vocabulary knowledge in other univiersities or institutions in Thailand.

c) The current study was restricted to 43 EFL students who are at the intermediate level at a university then it could be duplicated with more students in order to make a determination whether the results drawn from the current study are related.

d) The reading English newspaper corpus-based materials of this study investigated with only proficiency level (intermediate) thus the further study could be studied the effectiveness of corpus-based vocabulary activities on students with lower or higher proficiency levels such as elementary, pre-intermediate or higher that could be useful to get more understanding about the effectiveness of these materials. e) In this study, the corpus-based materials used only content words in order to develop the lessons; therefore the further study should be studied both function words and content words.

\section{REFERENCES}

Abdul Amir, A. R. Z. (2015). Utilization of request mitigators by Omani learners of English and native speakers: A comparative study. International Journal of Humanities, Arts and Social Sciences, 1(4), 156-172. doi:https://doi.org/10.20469/ ijhss.20004-4

Biber, D., Conrad, S., \& Reppen, R. (1994). Corpus-based approaches to issues in applied linguistics. Applied Linguistics, 15(2), 169-189. doi:https://doi.org/10.1093/applin/15.2.169

Boonkongsaen, N., \& Intaraprasert, C. (2014). Use of english vocabulary learning strategies by Thai tertiary-level students in relation to fields of study and language-learning experiences. English Language Teaching, 7(5), 59-70. doi:https:// doi.org/10.5539/elt.v7n5p59

Boonyarattanasoontorn, P. (2017). An investigation of Thai students' English language writing difficulties and their use of writing strategies. Journal of Advanced Research in Social Sciences and Humanities, 2(2), 111-118. doi:https://doi.org/ 10.26500/jarssh-02-2017-0205

Chaimongkol, U. (2000). Development of reading skills for english "business news" through computer assiited instruction: An independent study for the master of arts in English (Unpublished master's thesis). Graduate School, Khon Kaen Univeresity, Khon Kaen, Thailand.

Chansin, W. (2007). A study of English vocabulary learning strategies of good and poor learners of English at the university level (Unpublished master's thesis). Graduate School, Khon Kaen University, Khon Kaen, Thailand.

Clark, L. R. (1988). Business English and communication. New York, NY: McGraw-Hill Inc.

Duadsuntia, T. (2008). Using a keyword method to enhance learners' vocabulary recall and retention (Unpublished master's thesis). Graduate School, Khon Kaen University, Khon Kaen, Thailand.

Hilao, M. P. (2016). Creative teaching as perceived by English language teachers in private universities. Journal of Advances in Humanities and Social Sciences, 2(5), 278-286. doi:https://doi.org/10.20474/jahss-2.5.4

Junnak, C., \& Veerachaisantikul, A. (2016). Reporting verb in research projects of EFL English major students. Journal of Advanced Research in Social Sciences and Humanities, 1(1), 41-46. doi:https://doi.org/10.26500/jarssh-01-2016 
$-0105$

Krashen, S. (1989). We acquire vocabulary and spelling by reading: Additional evidence for the input hypothesis. The Modern Language Journal, 73(4), 440-464. doi:https://doi.org/10.1111/j.1540-4781.1989.tb05325.x

Krashen, S. D., \& Terrell, T. D. (1983). The natural approach: Language acquisition in the classroom. New York, NY: PrenticeHall.

Kyongho, H., \& Nation, P. (1989). Reducing the vocabulary load and encouraging vocabulary learning through reading newspapers. Reading in a Foreign Language, 6(1), 323-335.

Leki, I., \& Carson, J. G. (1994). Students' perceptions of EAP writing instruction and writing needs across the disciplines. Tesol Quarterly, 28(1), 81-101. doi:https://doi.org/10.2307/3587199

McCarthy, M., \& Carter, R. (1997). The importance of corpus-based research for language teachers. Cambridge, UK: Cambridge University Press.

Meara, P. (1996). The dimensions of lexical competence. In Brown, G., Malmkjaer, K. and Williams, J. (Eds.,) performance and competence in second language acquisition. Cambridge, UK: Cambridge University Press.

Nation, I. S. (2001). Learning vocabulary in another language. Cambridge, UK: Ernst Klett Sprachen.

Nation, P., \& Newton, J. (1997). Second language vocabulary acquisition: A rationale for pedagogy. New York, NY: Willey and John Son's.

Photi, O. C. (1997). Fundamentals of public relations. Bangkok, Thiland: Rajaphat Chadrakasem Institute Press.

Read, J. (2000). Assessing vocabulary. Cambridge, UK: Cambridge university press Cambridge.

Robb, T. N., \& Susser, B. (1989). Extensive reading vs. skills building in an efl context. Reading Foreign Language, 5(2), 239-251.

Scott, M. (2012). Lexical analysis software word smith tools version 6. New York, NY: Willy and Son's.

Simpson, R., \& Mendis, D. (2003). A corpus based study of idioms in academic speech. TESOL Quarterly, 37(3), 419-441. doi:https://doi.org/10.2307/3588398

Taher, M. A., Shrestha, P. N., Rahman, M. M., \& Khalid, A. K. M. I. (2016). Curriculum Linked Video (CLV) as a tool for English Language Teaching (ELT) at secondary school classrooms in Bangladesh. International Journal of Humanities, Arts and Social Sciences, 2(4), 126-132. doi:https://doi.org/10.20469/ijhss.2.20002-4

Unnanantn, T. (2017). Enhancing Thai undergraduates' ability on scholarly English presentation: Miller's model-based instruction. Journal of Advances in Humanities and Social Sciences, 3(2), 82-94. doi:https://doi.org/10.20474/jahss-3 .2 .2

Veerachaisanitkul, A. (2017). A corpus approach to high frequency words in English newspaper: A preliminary study. In Paper presented at 8th international conference on language, education, business, and law, Bangkok, Thiland.

Wallace, C. J. (1984). Modulation of the alkaline transition in cytochrome c and cytochrome ct by full or specific partial acetimidylation. Biochemical Journal, 217(3), 601-604. doi:https://doi.org/10.1042/bj2170601 